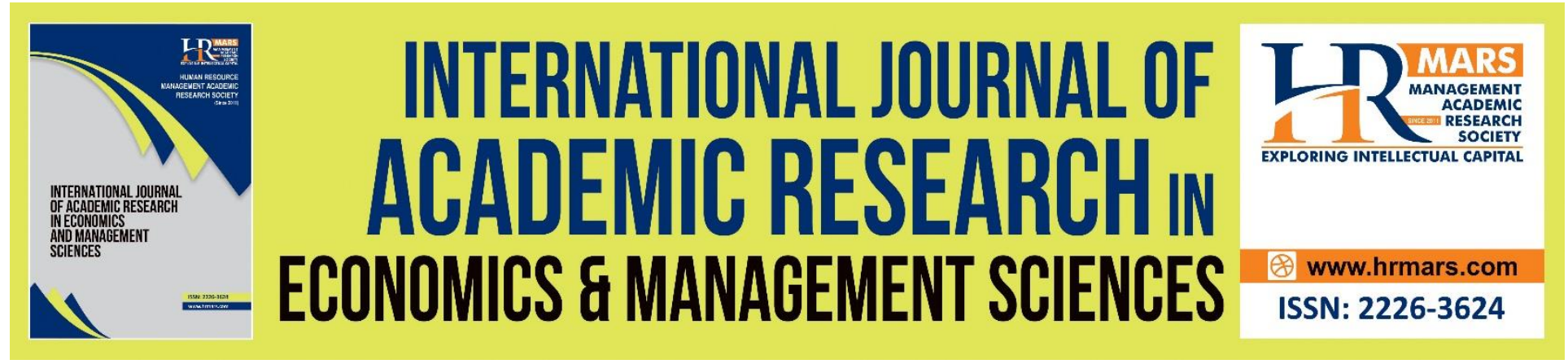

\title{
Determinant of Consumer Preference for Smartphone among Mobile Phone Users in Oyo State, Nigeria
}

Ajayi, Omobola. M., Ogundipe, Folake. C., Ayeni, Olapade. G.

To Link this Article: http://dx.doi.org/10.6007/IJAREMS/v10-i1/9703

DOI:10.6007/IJAREMS/v10-i1/9703

Received: 05 February 2021, Revised: 27 February 2021, Accepted: 15 March 2021

Published Online: 30 March 2021

In-Text Citation: (Ajayi et al., 2021)

To Cite this Article: Ajayi, O. M., Ogundipe, F. C., \& Ayeni, O. G. (2021). Determinant of Consumer Preference for Smartphone among Mobile Phone Users in Oyo State, Nigeria. International Journal of Academic Research in Economics and Managment and Sciences, 10(1), 259-268.

Copyright: (C) 2021 The Author(s)

Published by Human Resource Management Academic Research Society (www.hrmars.com)

This article is published under the Creative Commons Attribution (CC BY 4.0) license. Anyone may reproduce, distribute, translate and create derivative works of this article (for both commercial and non-commercial purposes), subject to full attribution to the original publication and authors. The full terms of this license may be seen at: http://creativecommons.org/licences/by/4.0/legalcode

Vol. 10, No. 1, 2021, Pg. 259 - 268

http://hrmars.com/index.php/pages/detail/IJAREMS

JOURNAL HOMEPAGE

Full Terms \& Conditions of access and use can be found at http://hrmars.com/index.php/pages/detail/publication-ethics 


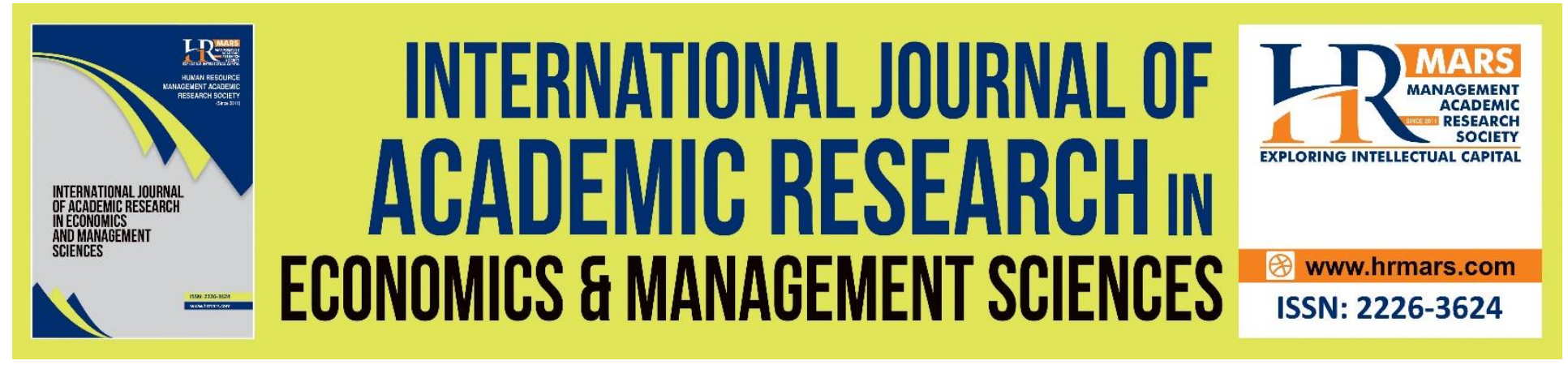

\title{
Determinant of Consumer Preference for Smartphone among Mobile Phone Users in Oyo State, Nigeria
}

\author{
Ajayi, Omobola. M., Ogundipe, Folake. C., Ayeni, Olapade. G. \\ Ekiti state university, Ado-Ekiti, Department of Business Administration \\ Email: Omobola.ajayi@eksu.edu.ng
}

\begin{abstract}
The study investigated the determinant of consumer preference of smartphone among mobile phone users. In order to accomplish the objectives of the study, a sample of 381consumers were taken from 45000 population of students in Oyo state, Nigeria by using Krejcie and Morgan sample size. Four factors i.e. price, brand, packaging, and quality were used to check the preference of consumers and data were analyzed through the use of correlation and multiple regressions. From the analysis, it was clear that price of phone exerts an insignificant positive effect on consumer's preference, followed by quality; the most important variable amongst all is the packaging of the phone which was discovered to exert significant effect that determines consumer preference and it also acted as a motivational force that influences them to go for a mobile phone. The study suggested that if mobile phone manufacturer should consider making a quality and well package product, price is of no significant to youth in Oyo State, Nigeria, i.e., youth will buy expensively for a quality and well packaged product.
\end{abstract}

Keywords: Consumer Preference, Smartphones, Price, Quality, Brand and Packaging

\section{Introduction}

Now a day's mobile phones have become a basic element of individual communication across the globe in the past ten years, consumer research has dedicated little precise concentration to motives and choice underlying the mobile phone buying decision process (Karjaluoto, Karvonen et al., 2005).

It has been not so recent that the telecommunications industry has been seeing an incremental graph and growth especially in the product domain. Today's market is highly volatile as regards to the dynamicity in the market with respect to brands and prices available in almost all the goods and services. Cell phones have seen capitalizing the market with a huge potential to grow as well as sustain. A lot of surveys are conducted world over to identify and understand customer preferences in cell phone buying and because of highly competitive and rapidly changing business environment, has therefore prompted firms that plans to succeed in its goal has to do a 
continuous observation of the consumer behavior and their preference because consumers are the kings in the business world (Anojan \& Subaskaran, 2015). This suffix to say that a firm must have a bird's eye-view on its product life cycle right from the stage of launching to saturation. This demands that marketers remain alert and active at all time to winning permanent and loyal customers in the consumer market (Thangasamy \& Patikar, 2014).

Consumers are individuals and households that buy the firm's product for consumption (Kolter, 2004). It is term often used to describe two different kinds of consuming entities: the personal consumers and the organizational consumers (Krishna, 2010). The activities these consumers undertake when obtaining, consuming and disposing of product and a service is known as consumer behavior. However, before consumers take any of the aforementioned steps, he/she is motivated by a number of factors. Consumer behavior involves studying how people buy, what they buy, when they buy and why they buy. (Blackwell, Miniard \& Engel, 2006).

While individual consumers may not give much thought to why they prefer one product over another, for businesses and marketers who make a living based on consumer demand, it is pretty much a science. Among all the development and innovations that have cropped up in modern times, Smart phone devices have had one of the fastest household adoption rates of any technology in the world's modern history. The growth of smart phones in the $21^{\text {st }}$ century has been phenomenal. Nowadays, Smart phones have become an integral part of human daily life and personal communication across the globe. Almost everyone possesses a smart phone. Due to its integral nature, one simply cannot live without it.

Consumers are betwixt alternative most times due to some factors that they cannot but concern themselves with the alternative collection of product available around them and within their reach. These factors stand as some sub-variable under the independent variable (Consumer preference). They include: Price, brand, quality, and packaging just to mention but few.

Numerous studies have been conducted to understand the consumer buying behavior one of them include Manali Khaniwale (2015) he conducted a study which analyzed the theoretical aspects of consumer buying behavior and the factors that influence it. According to Aggarwal (2004) prior research has examined differences in how consumers perceive and evaluate brands, for example, through investigating brand equity, brand personality and brand extensions. More recently, researchers have noted that consumers differ not only in how they perceive brands but also in how they relate to brands. This line of research has suggested that people sometimes form relationships with brands in much the same way in which they form relationships with each other in a social context (Aggarwal, 2004).

Consumers are individuals and household that buys the firm's product for personal consumption (Kolter, 2004). Zameer, Saeed \& Abass (2012) research work on consumer Buying Behavior of mobile phone device, they focused more on the features that have been reviewed by existing writings in urban consumers and rural consumers in Pakistan. The only limitation of this research is that it was done in Pakistan and have not been done in Nigeria and the buying behavior of the two countries will surely be different. Therefore, the problem this research addresses is to investigate the determinants of consumer preference of smartphone among mobile phone users in Oyo state, Nigeria. 


\section{Conceptual Clarification}

\section{Consumer Preference}

Consumer preference explains how an individual rank a collection of goods and services or prefers one collection over another. This definition assumes that consumer ranks goods and services by the amount of satisfaction and utility they derive from the product. The preferences of certain consumers are also determined by their level of income, the price of the goods and service and the willingness and ability of the consumer to purchase the product at the time needed (study.com/Iconsumer-preference, 2019)

A consumer preference assumes that the consumer can choose consistently and among alternative goods and services available for purchase. The consumer must prefer one set of goods or services over another or treat all as equally beneficial. Consistency is an issue when the consumer more than two alternatives. If a consumer rank brand of mobile phone as better than the other or feels there's more utility and satisfaction to derive from the mobile phone type compared to another at every time purchases are made, the consumer will always go for its brand preference. Customer satisfaction is the feelings of pleasure and disappointments resulting from the comparison of products, perceived performance or outcomes in relation to the person's prior expectations. The satisfaction is the level of a person's felt state resulting from comparing a products perceived performance (outcomes) in relation to the person's expectation (Kotler, 2009). Seth (2008) analyzed that there is relative importance of service quality attributes and showed that responsiveness is the most importance dimension followed by reliability, customer perceived network quality, assurance, convenience, empathy and tangibles. Liu (2002) found that the choice of a cellular phone is characterized by two attitudes: attitude towards the mobile phone brand on one hand and attitude towards the network on the other.

\section{Conceptual Framework}

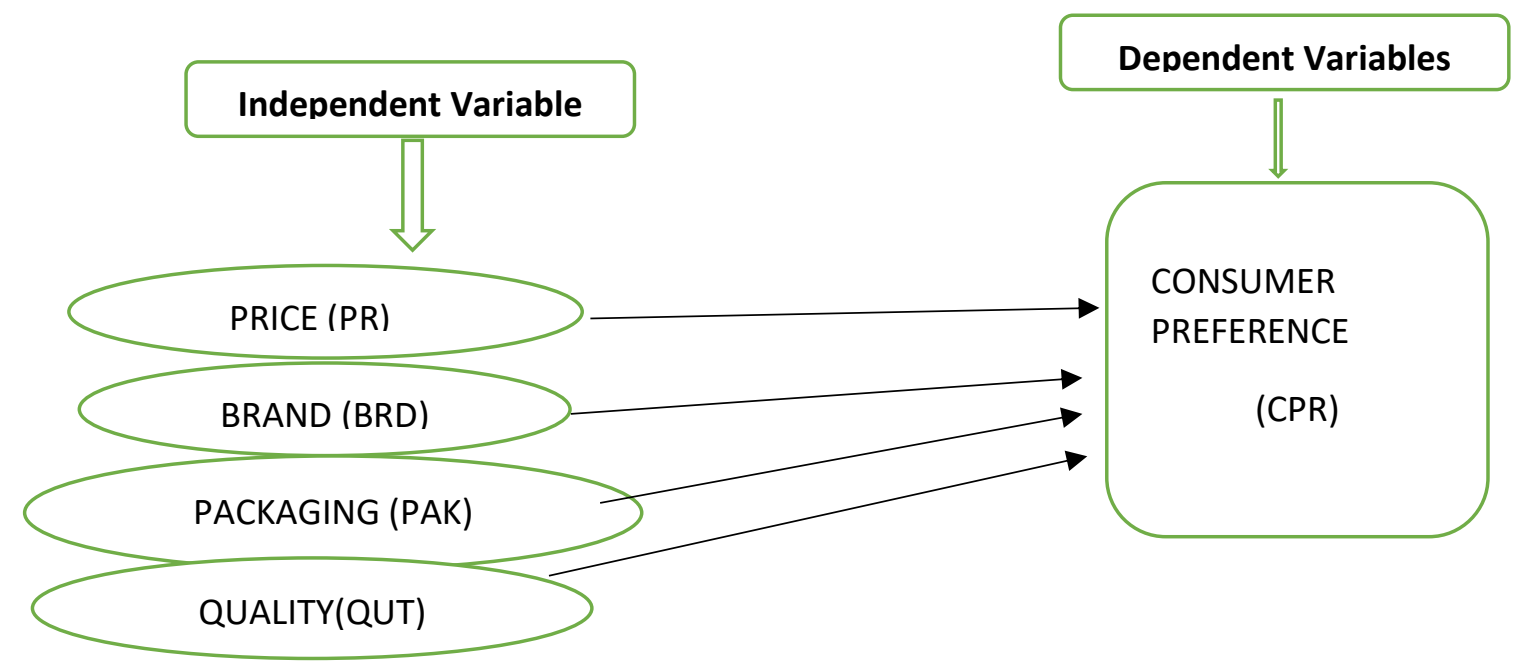


INTERNATIONAL JOURNAL OF ACADEMIC RESEARCH ECONOMICS AND MANAGEMENT SCIENCES

Vol. 10, No. 1, 2021, E-ISSN: 2226-3624 ㄷ 2021 HRMARS

\section{Methodology}

\section{Population and Sample size for the Study}

Population is defined by ErlindaDionco-Adetayo (2011) as the entire group of people, events or things of interest that the researcher wishes to investigate. In respect to this research work the population of this study is comprised of 45000 in Oyo-state. According to Krejcie and Morgan sample size table, a total number of 381 students was sampled for this study

\section{Method of Data Analysis}

The collected were analyzed using descriptive and inferential statistical methods. In descriptive statistics, simple frequency counts and percentages will be used to answer the research question while the inferential statistics will be used to test the hypotheses. correlation and multiple regressions analysis will be used to test the hypotheses at 0.05 level of significance which made good presentation and analysis of data and testing of the hypotheses. Correlation is the statistical technique for establishing the extent of relationship or association between two or more variables. Correlation coefficient would reveal both the magnitude and direction of relationship between the variables.

\section{Results}

\section{Distribution of respondents by Phone Brand}

Table 1.1 reveals the distribution of the respondents based on phone brand. The table reveals that $12(3.1 \%)$ of the respondents prefers Nokia brand, 107 (28.1\%) of the respondents are Tecno fans, 163 (42.7\%) prefers Infinix, while, 64 (16.7\%) of the respondents are IPhone users while 35 $(9.2 \%)$ of the total respondents are users of other brands.

\section{Table 1.1 Distribution of respondents by Phone Brand}

\begin{tabular}{|l|l|r|r|r|r|}
\hline \multicolumn{2}{|c|}{} & Frequency & Percent & Valid Percent & \multicolumn{1}{c|}{$\begin{array}{c}\text { Cumulative } \\
\text { Percent }\end{array}$} \\
\hline \multirow{4}{*}{ Valid } & Nokia & 12 & 3.1 & 3.1 & 3.1 \\
\cline { 2 - 6 } & Tecno & 107 & 28.1 & 28.1 & 31.2 \\
\cline { 2 - 6 } & Infinix & 163 & 42.7 & 42.7 & 73.9 \\
\cline { 2 - 6 } & IPhone & 64 & 16.7 & 16.7 & 90.6 \\
\cline { 2 - 6 } & Others & 35 & 9.2 & 9.2 & 100.0 \\
\cline { 2 - 6 } & Total & 381 & 100.0 & 100.0 & \\
\hline
\end{tabular}


INTERNATIONAL JOURNAL OF ACADEMIC RESEARCH ECONOMICS AND MANAGEMENT SCIENCES

Vol. 10, No. 1, 2021, E-ISSN: 2226-3624 @ 2021 HRMARS

Correlation Analysis

Table 1.2: Correlation Matrix

\begin{tabular}{|c|c|c|c|c|c|}
\hline & CPR & PR & BRD & QUT & PAK \\
\hline CPR & 1 & & & & \\
\hline PR & 0.440 & 1 & & & \\
\hline BRD & 0.334 & $0.701^{* *}$ & 1 & & \\
\hline QUT & 0.324 & $0.706^{* *}$ & $0.629^{* *}$ & 1 & \\
\hline PAK & 0.357 & $0.634^{* *}$ & $0.843^{* *}$ & $0.792^{* *}$ & 1 \\
\hline
\end{tabular}

Source: Author's Computation, (2021)

Table 1.2 presents correlation coefficient for pairs of variables used in the study. Specifically, the table reported correlation statistics of $0.440,0.334,0.324,0.357,0.701,0.706,0.634,0.629$, $0.843,0.792$ for CPR and PR; CPR and BRD; CPR and QUT; CPR. and PAK. It also shows PR and BRD; PR and QUT, PR and PAK, BRD and QUT, BRD and PAK, QUT and PAK respectively. The result revealed that there is positive relationship between pairs of variables used in the study. Notably the result showed that consumer preference increases overtime alongside increases in price, brand, quality as well as packaging.

\section{Regression Analysis}

Table 1.3: Regression Estimation Result

Dependent Variable: Consumer Preference

\begin{tabular}{|c|r|r|r|r|}
\hline Variable & Coefficient & \multicolumn{1}{l|}{ Std Error } & t-statistics & \multicolumn{1}{l|}{ Prob. } \\
\hline C & 9.367 & 4.356 & 2.150 & 0.048 \\
\hline PR & 0.398 & 0.331 & 1.202 & 0.248 \\
\hline BRD & 0.156 & 0.459 & 0.340 & 0.739 \\
\hline QUT & 0.115 & 0.329 & 0.349 & 0.732 \\
\hline PAK & 1.269 & 0.491 & 2.585 & 0.008 \\
\hline
\end{tabular}

R-Squared $=0.613$

Adjusted R-Square $=0.603$

F-statistics $=11.014$

$\operatorname{Prob}($ F-statistics $)=0.002$

Result of the regression estimation presented in table 1.3 revealed coefficient estimates of 0.398 , $0.156,0.115,1.269$, with the probability values of $0.248,0.739,0.732,0.008$ for price brand, quality as well as packaging. The result revealed that all the explanatory variables exert positive impact on consumer's preference for smartphones. This implies that increase in price, brand uniqueness, quality as well as packaging will lead to a corresponding increase in preference of consumers as represented to the tune of average score of $0.398,0.156,0.115,1.269$. The probability values presented in table 4.10 showed that among all the explanatory variables only packaging exert significant positive impact on consumer preference. R-square statistics reported in table 1.3 stood at 0.613 , which implies that about $61 \%$ of the systematic variation in consumer's preference can be explained by joint variation in price, brand, quality as well as 
packaging. F-statistics and probability values reported in table 4.10 reflect that the model is a good fit, with the probability value of the reported statistics less than 0.05

\section{Discussion}

From the empirical investigation conducted in the study with the focus of investigating the determinant of consumer preference of smartphone among mobile phone users in Oyo State revealed the following discoveries: First, the study discovered that price exert a positive but insignificant impact on buying behavior of consumers. The result reflect that consumer tends to buy more of phone that are expensive, this might be attributed to the fact that mobile phone is considered an ostentatious product in which every individual consumer purchase on the basis of some prevailing factors such as style, fashion, and vogue trend etc. since most of the consumers anticipates for newly made product and no one wants to be left out using the latest. Therefore, in this context, it can be deduced that higher price of mobile phone culminates into higher preference among students in Oyo state. However, the study found that the positive interrelationship between price and preference is not statistically significant, which could reflect the fact that the study sampled university mobile phone users.

Secondly, the study discovered that brand of a product exerts insignificant positive impact on consumer's preference. This result can be agreed upon based on the growing competition in the business world. This has over the years make organizations to sit back and come up with strategies by incorporating some features in their products in order to serve their customers better and to keep them away from consuming their competitors' products, as a result of the competition the importance of mobile phones to various individuals has remained enormous through the various functions available in different phone brands. In a nutshell the result reflects that brand is one of the determinants of consumer buying behavior in the context of rural and urban consumers in Ekiti state.

Thirdly, the study discovered that quality exert positive and insignificant impact on consumer's preference. The quality of a product goes a long way determining the reaction of consumers towards the purchase of a product. Therefore, as a company strives to make goods available for the consumers, they should also ensure that the available products are attached with the sense of quality so as to ensure customer's retention as well as increasing the numbers of their final consumers.

Finally, the study discovered that packaging exerts significant positive impact on consumer's Preference. This discovery established that the way mobile phone is packaged tends to significantly influence the determinant of consumer preference, thus reflecting the important role played by packaging in the mobile phone industry, and also reaffirmed the fact that packaging does not only provide protection to the product but also act as a promotional tool, because sometimes, consumers assesses the quality of the product from its packaging.

\section{Conclusion and Recommendations}

Based on the discoveries and the analysis conducted in the study, it can be concluded that high price is a notable factor which influences the consumer's preference, quality is a key determinant of how well a consumer's preference can be measured, that brand exerts a positive impact that 
cannot be undermine in determining the consumer's behavior, and finally, it can be concluded that packaging exerts a notable significant impact on consumer's preference

\section{Recommendation}

Mobile phone producing companies should ensure that the price tag on their products correlate with inbuilt values of their product so that consumers can get commensurate value for money spent of their product, so as to keep a long-standing consumer loyalty and patronage. Management should ensure that products made by them are attached with the sense of quality as this goes a long way in determining the stay or exit of customers. Management of mobile phones producing company should incorporate some innovative packaging ideas that will increase the scope of marketing their product as this will serve as a way of ensuring customers to quick access to quality product.

\section{References}

Abley, J. (2000). Stated preference techniques and consumer decision making: New challenges to old assumptions, report school of management working papers.

Anandan, C., \& Deepa, A. (2004). Influence of packaging in Brand Selection with Respect to Bar Chocolate. Indian Management, 1(1).

Armstrong, G., \& Kotler, P. (2000). Marketing: An Introduction, (10th ed), Prentice- Hall International Editions, USA

Blackwell, R. D., Miniard, P. W., \& Engel, J. F. (2006). Consumer behavior, (10edt) Thomson SouthWestern, Boston.

Chatterje, T., \& Shukla, A. (2017). Consumer's Preference to Specific Features in Mobile Phones: A Comparative Study

Das, D. (2012). An empirical study of factors influencing buying behaviour of youth consumers towards mobile handsets: A case study in coastal distrcts of Odisha. Asian Journal of Research in Business Economics and Management, 2(4), 68-82.

Gupta, S. (1988). Impact of sales promotions on when, what, and how much to buy.Journal of Marketing Research, 342-355.

Hakoama \& Hakoyama, S. (2011). The impact of cell phone use on social networking anddevelopment among college students, The AABSS Journal, 15, 1-20.

Davis, H. L. (1970). "Dimensions of Marital Role in Consumer Decision Making. Journal of Marketing Research, II(2), 168-177.

Kotler, P. (2004). Ten deadly marketing sins: signs and solutions. Wiley

Lee, J., \& Feick, L. (2001). The impact of switching costs on the customer satisfaction-loyalty link: mobile phone service in France. Journal of services marketing 15(1), 35-48.

Li, S., \& Li, Y. (2010). An Exploration of the psychological factors influencing college student consumption of mobile phone in West China.International Journal of Business and Management, 5(9), P132.

Ling, W. H., \& Salvendy, G. (2006). Diversified users' satisfaction with advanced mobile phone features, Universal Access in the Information Society, 5, (2), 239-249.

Mack \& Sharples, S. (2009). The importance of usability in product choice: A mobile phone case study, Ergonomics, 52(12), 1514-1528. 
Malasi, J. M. (2012). Influence of product attributes on mobile phone preference among university students: A Case of undergraduate students. International Journal of Academic Research in Economics and Management Sciences. 1(6), 10-16

Messay, S. (2013). Consumer Buying behavior Of Mobile Phone Device

Pakol. (2010). An investigation of consumer behavior in mobile phone markets in Finland. InSubmission to the 32nd EMAC conference, Track: New Technologies and E-Marketing.

Rahman, Z., \& Bhattacharyya, S. (2003). Sources of first mover advantages in emerging markets an Indian perspective.European Business Review, 15(6), 359-369.

Solomon, M. (2006). Consumer behavior.A European Perspective. England, ( $\left.3^{\text {rd }} \mathrm{ed}\right), 287-427$.

Soomro, H. J., Ghumn, I. A. (2013). An analysis of Consumer Behaviour on Mobile Phone In Sindh

Subramanyam \& Venkateswarlu. (2012). Factors influencing buyer behaviour of mobile phone buyers in Kadapa District. Indian Journal of Research, 1(11), 3-5

Szmigin, I., \&Carrigan, M. (2001). Time, Consumption and the older consumer: An interpretive study of the cognitively young. Psychology and Marketing, 18(10): 1091-1116.

Thangasamy, E., \& Gautam, P. (2014) Factors Influencing Consumer Buying Behavior

Anjan, V., \&Subaskaran, T. (2015). Consumer's Preference and Buying Behaviour on Soft Drinks: A Case Study in Northern Province Sri Lanka

Williams, T. G. (2002). Social class influences o purchase evaluation criteria. Journal of consumer marketing, 19(3), 249-276.

Wilska, T. A. (2003). Mobile phone use as part of young people's consumption styles.Journal of Consumer Policy, 26(4):441-463

Zameer, H., Saeed. R., and Abass, R. (2012) Mobile Phones Buying Behavior of Consumers; A Comparative Study of Rural and Urban Consumer in Pakistan

Zhou, N., \& Shanturkovska, G. (2011). Chinese consumer behavior in the mobile phone market: Nokia case (Doctoral dissertation, Gotland University)

Abley, J. (2000). Stated preference techniques and consumer decision making: New challenges to old assumptions, report school of management working papers.

Ahmed, Z., Gull, M., \& Rafiq, U. (2015). Factors Affecting Consumer Switching Behavior: Mobile Phone Market in Manchester U.K

Anandan, C., \& Deepa, A. (2004). Influence of packaging in Brand Selection with Respect to Bar Chocolate. Indian Management, 1(1).

Armstrong, G., \& Kotler, P. (2000). Marketing: An Introduction, (10th ed), Prentice- Hall International Editions, USA

Blackwell, R. D., Miniard, P. W., \& Engel, J. F. (2006). Consumer behavior, (10edt) Thomson SouthWestern, Boston.

Chatterje, T., \& Shukla, A (2017). Consumer's Preference to Specific Features in Mobile Phones: A Comparative Study

Cochran, W. G. (1977). Sampling techniques (3rd ed.). New York: John Wiley \& Sons.

Das, D. (2012). An empirical study of factors influencing buying behaviour of youth consumers towards mobile handsets: A case study in coastal distrcts of Odisha. Asian Journal of Research in Business Economics and Management, 2(4), 68-82.

Gupta, S. (1988). Impact of sales promotions on when, what, and how much to buy.Journal of Marketing Research, 342-355. 
Hakoama \& Hakoyama, S. (2011). The impact of cell phone use on social networking anddevelopment among college students, The AABSS Journal, 15, 1-20.

Davis, H. L. (1970). "Dimensions of Marital Role in Consumer Decision Making. Journal of Marketing Research, II(2), 168-177.

Kotler, P. (2004). Ten deadly marketing sins: signs and solutions. Wiley

Lee, J., \& Feick, L. (2001). The impact of switching costs on the customer satisfaction-loyalty link: mobile phone service in France. Journal of services marketing 15(1), 35-48.

$\mathrm{Li}, \mathrm{S} .$, \& Li, Y. (2010). An Exploration of the psychological factors influencing college student consumption of mobile phone in West China.International Journal of Business and Management, 5(9), P132.

Mack \& Sharples, S. (2009). The importance of usability in product choice: A mobile phone case study, Ergonomics, 52(12), 1514-1528.

Malasi, J. M. (2012). Influence of product attributes on mobile phone preference among university students: A Case of undergraduate students. International Journal of Academic Research in Economics and Management Sciences. 1(6), 10-16

Messay, S. (2013). Consumer Buying behavior Of Mobile Phone Device

Pakol. (2010). An investigation of consumer behavior in mobile phone markets in Finland. InSubmission to the 32nd EMAC conference, Track: New Technologies and E-Marketing.

Rahman, Z., \& Bhattacharyya, S. (2003). Sources of first mover advantages in emerging markets an Indian perspective.European Business Review, 15(6), 359-369.

Saaksjarvi, M. (2003). Consumer adoption of technological innovations. European Journal of Innovation Management 6(2), 90-100.

Saif, N., Razzaq, N., Amad, M., \&Gul, S. (2012). Factors affecting consumers' choice of mobile phone selection in Pakistan. European Journal of Business and Management, 4(12), 1626.

Leon, S. G., \&Kaunk Leslie Lazar, (2006). Consumer Behavior, Pearson Education, (8th Ed.)

Singh, J. (2011). A Comparison of rural and urban buying of consumer durables. Global Journal of Management and Business Research 11(5).

Solomon, M. (2006). Consumer behavior.A European Perspective. England, ( $3^{\text {rd }}$ ed), 287-427.

Subramanyam \& Venkateswarlu (2012). Factors influencing buyer behaviour of mobile phone buyers in Kadapa District. Indian Journal of Research, 1(11), 3-5

Sun, T., \& Wu, G. (2004). Consumption patterns of Chinese urban and rural consumers. Journal of Consumer Marketing, 21(4), 245-253.

Szmigin, I., \&Carrigan, M. (2001). Time, Consumption and the older consumer: An interpretive study of the cognitively young. Psychology and Marketing, 18(10): 1091-1116.

Thangasamy, E., \& Dr. Gautam, P. (2014) Factors Influencing Consumer Buying Behavior

Anjan, V., \&Subaskaran, T. (2015). Consumer's Preference and Buying Behaviour on Soft Drinks: A Case Study in Northern Province Sri Lanka

Williams, T. G. (2002). Social class influences o purchase evaluation criteria. Journal of consumer marketing, 19(3), 249-276.

Smadi, Z. A. (2011), The Consumer Decision Making Styles of Mobile Phones among the University Level Students in Jordan. International Bulletin of Business Administration. Issue 10. 